Received: 5.4.2020; Revised: 17.08.2020; Accepted: 15.09.2020; Published online: 22.9.2020

\title{
AGRICULTURAL CREDIT GUARANTEE SCHEME FUND AND ITS EFFECT ON AGRICULTURAL OUTPUT IN NIGERIA
}

\author{
Jonathan REUBEN *I (D), Christiana Mlumun NYAM ${ }^{2}$ (D), Daniel Tukura RUKWE ${ }^{3}$ (DD
}

\author{
Address: \\ ${ }^{1}$ Taraba State University, Faculty of Agriculture, Department of Agricultural Economics and Extension, PMB 1167, \\ Jalingo, Taraba State, Nigeria \\ ${ }^{2}$ Zenith Bank Plc, PMB 1034, Jalingo, Taraba State, Nigeria \\ ${ }^{3}$ Ahmadu Bello University, National Agricultural Extension and Research Liaison Services, PMB 1067, Zaria, Nigeria \\ *Corresponding author: jonnyato4@yahoo.com
}

\begin{abstract}
Research Background: Agricultural production in Nigeria experiences the challenge of inadequate funding particularly by farmers in rural areas. In an attempt to enhance farmers' access to credit, the federal Government of Nigeria set up Agricultural Credit Guarantee Scheme Fund (ACGSF) to boost funding in the sector. But to what extent the Scheme has affected the output of agricultural sectors in the Country for the period under review is of great concern especially to policy makers in the Country.

Purpose of the article: The study analysed trends and effect of Agricultural Credit Guarantee Scheme Fund (ACGSF) on farmers' agricultural output (GDP) in Nigeria. The specific objectives of the study were to examine the trend in volume of loans guaranteed by ACGSF to farmers and determine the effect of ACGSF on agricultural output for the period under review.

Methods: Secondary data were sourced from Central Bank of Nigeria bulletins, National Bureau for Statistics data base and other financial bulletins. The data were analysed using descriptive and inferential statistics.

Findings and value added: The trend revealed that the supply of funds to agricultural sector from the scheme has always increased in a wobbly pattern. It was found that funds guarantee to crop-sub sector increased steadily from 1998 to 2009. The result shows that credit supplied to livestock sub-sector by ACGSF rose consistently in the period under review but initially declined from 1998-2007. The multiple determination coefficients $\left(\mathrm{R}^{2}\right)$ of 0.8523 was obtained and the coefficients of ACGSF on crop sector, livestock sector and fishery sector were $0.1607,0.2320$ and 0.2110 respectively. The signs were all positive and significant at $1 \%$ and $5 \%$ levels. The study concludes that ACGSF has a positive effect on agricultural output in Nigeria. Hence, it is recommended that government, agricultural agencies and allied bodies should give more preference to the scheme to boost agricultural production. Government should increase funding to the scheme in order to diversify the earnings to eliminate her dependency on oil export.
\end{abstract}

Key words: credit; agricultural credit guarantee scheme fund; farmers; output; Nigeria.

JEL: R52; R58; H41

\section{INTRODUCTION}

Agricultural Credit Guarantee Scheme Fund (ACGSF) came into existence in 1977 to motivate financial institutions to increase lending to the agricultural sector in the country. The essence was to ameliorate the challenges encountered by farmers in their attempts to access credit which would eventually translate to increased agricultural productivity in the country. Financial institutions view agricultural sector as a high risk sector, also most of the farmers particularly the poor farmers do not have the collateral required to obtain credit from financial institutions. As a result of these, financial institutions are usually not interested in lending to agribusinesses. AGCSF in an endeavour to enhance farmers' access to credit has put in place a strategy that assures financial institutions the recovery of $75 \%$ of the defaulted amount (in case borrowers default). From the beginning of the scheme, loans were issued at reduced interest rates but eventually market-determined rates are applied under the now operational Interest Drawback Programme (IDP). In the $34 / 35$ years of operation, precisely in June 2012, the scheme had guaranteed about 55 billion NGN $(347,452,541$ USD) of agricultural loans to 770,438 projects (farmers) $(\mathbf{C B N}, \mathbf{2 0 1 3})$.

There is thus a need to evaluate the activities and the performance of the scheme in relation to domestic food supply. Various studies have shown that Credit plays an important role in enhancing agricultural productivity of the farmer (Nwosu et al., 2010). The general purpose of the Nigerian Agricultural Credit Guarantee Scheme Fund is to encourage banks to lend to those engaged in agricultural production and agro-processing activities. Thus, the specific objective of the scheme is the stimulation of total agricultural production for both domestic consumption and export; by encouraging financial institutions to participate in increasing the productive capacity of agriculture through a capital 
lending programme. The scheme provides guarantee on loans granted by financial institutions to farmers for agricultural production and agro-allied processing. The fund's liability is limited to $75 \%$ of the amount in default net of any amount realized by the lending bank from the sale of the security pledged by the borrower. Since the inception of the scheme in 1978, the aggregate number of loans to agriculture hasalways been on the rise from a negligible number of 341 loans amounting to 11.28 million NGN (18,613,861 USD) in 1978 to 3,571 loans valued at 218.60 million NGN $(1,679,600.46$ USD) as at May, 2006 (Yusuf et al., 2015).

Accessing agricultural credit in Nigerian has been a challenge to most farmers because they do not have the collateral required to obtain credit from financial institutions. Another challenge is that financial institutions shy away from lending to agricultural sector because they perceive it to be a high risk sector. Socio-economic characteristics of Nigerian farmers also contribute to inaccessibility to credit. Furthermore, considering the nature of farming in a subsistence economy like Nigeria, where agriculture is still characterized by low mechanization, high labour input, low productivity, poor skills and production inefficiency, it has not been easy to maintain serious private sector participation in the sector without some form of incentives. Thus, in order to set in motion, the needed desire towards the agricultural sector, the government initiates and implements policies that encourage the elevation of agriculture from subsistence to commercial level. It was in acknowledgment of these realities that the Federal Government at various periods put in place credit policies and established credit institutions and schemes that could enhance the flow of agricultural credit to farmers (Udoka, 2015). One of such laudable Schemes has been the Agricultural Credit Guarantee Scheme Fund (ACGSF).

Agricultural production in Nigeria experiences the challenge of inadequate funding particularly by farmers in rural areas. In an attempt to enhance farmers' access to credit, the federal Government of Nigeria has put in place several schemes. Despite the huge efforts to ease farmers' access to agricultural credit, the average farmer still experiences the challenge of inaccessibility to agricultural credit. This has been compounded the unwillingness of commercial banks to lend to the sector based on the perceived risk and low returns related to the sector. Agricultural Credit Guarantee Scheme Funds (ACGSF) is particularly a safe saver for the small scale farmers as it encourages financial institutions to partake in financing agricultural production. More so, the scheme is aimed at moving farmers from subsistence level of farming to commercial agriculture in the country. In spite of all these efforts, the average Nigerian farmer still experiences the challenge of inadequate funds for agribusiness. Accordingly, this study was carried out to examine effect of the scheme on agricultural output in Nigeria from 1998 $-2017$.

The research questions to answer in this work are: What are trends in the annual volumes of credits guaranteed by ACGSF from the year 1998 - 2017? What is the effect of ACGSF on the agricultural output in Nigeria?
The broad objective of the study was to analyse trend in the flow of ACGSF credit to farmers and its effect on agricultural output in Nigeria. The specific objectives were to examine the trend in the annual volume of credits guaranteed by ACGSF from the year 1998 - 2017 and to analyse the effects of credit volumes guaranteed by ACGSF on agricultural output in Nigeria.

\section{LITERATURE REVIEW}

\section{Concept of agricultural credit}

Sodeeqet al. (2019) defined credit as means of providing fund by an organisation or individual to another organisation or group of persons in an understanding that the collected sum will be paid back as contained in the agreement signed by both parties. It is the exchanging of legal tender with an agreement to pay back at a later date. If the borrower lacks the desire and capacity to payback, the agreement to payback at later date may not be kept. Credits could be cash or materials in form of inputs or services rendered to the lender. Credit could lead to increase in productivity and profitability in agribusiness (Ashaolu et al., 2011). Anthony (2010) stated that credit is a good means of acquiring facilities for improving agricultural production to increase participants' income and better standard of living in Nigeria. Furthermore, it will generate confidence in farmers the optimism and determination to venture into new fields of agricultural production.

Accessed funds have to be properly managed in order to yield the desired results. Proper management ensures that funds are used appropriately otherwise they will be misappropriated or diverted. Previous studies have shown that when agricultural funds are used appropriately, adoption mechanization which will eventually result to expansion of the agricultural business and income is achievable (Olagunju and Ajiboye, 2010). Yunus (2011) observed that unavailability of credit to peasants and privileged farmers hinder diversification of agricultural production as such retarded economy growth of the country. The rules of engagements set by the borrowers in terms of character, capability, collateral, and confidence constraints so many beneficiaries from accessing it. Furthermore, the costs involved in obtaining loans from the lenders couple with the rate of decay in our infrastructures reduce the level of agricultural production in the country. The consequence effect of high cost of obtaining loan made farmers not to achieve their target production level and hence government policy and effort in improving farmers' standard of living frustrated.

Accessing agricultural loans in Nigeria remains one of the farmer's greatest nightmares in the development of agricultural production in Nigeria. The reasons for the limited access to agricultural loans by farmers are often linked to the high cost of administering such loans and the perceived high default rates among farmers (Nwankwo, 2017). Commercial banks in Nigeria, as major players in the country's credit intermediation sector are expected to be very visible in the provision of agricultural loans, hence the decision of the government to channel their agricultural schemes through them. But the expected change for increased accessibility to agricultural loans and 
consequently increase in agricultural production remains a mirage as small holder farmers still do not have access to adequate finance (Badiru, 2010).

\section{Theoretical review}

The structural change theory designed by Nobel laureate W. Arthur Lewis in the mid-1950s was subsequently changed and redesigned and used by economist in developing agriculture activities. This actually reduce the over reliance on small peasant means of agricultural production in most of the developing countries (Orok and Ayim, 2017). Another aspect of this theory mentioned that has continuous improvement in agricultural productivity could be achieved when there is a good supporting structure to develop and gives the required motivations and opportunities to the agricultural sector.

Chamber and Conway (1991) further developed the reliable livestock theory for capabilities, which encompasses capital and other social inputs as well as other farming activities needed for a means of living. It further stated that the theory forecasted that increased output can only be obtained by ensuring secured ownership of, or access to capital inputs and income earning activities such as; reserves and assets to offset risk ease stocks and meet contingencies as well as improvement and maintenance of productive resources on a long term basis. Therefore, raising agricultural productivity (good output) is not just food affordability but the effort to produce food and obtain more income on a long term basis by farmers. In order have a successful attainment in agricultural productivity, the economic development theory emphasised that a technical, institutional and financial supports in terms of incentives needed to boost productivity level of peasant small holder farmers (Orok and Ayim (2017). They further added that an effort to raise the economic development of agricultural activities, financial scheme act dual function of increasing the purchasing power and making inputs available for industrial development in any given country.

Role and problems of ACGSF in economic development Agricultural funds are regarded as essential tool for agricultural expansion and rural development, this is because they increase productivity and improve standard of living thereby, breaking the vicious cycle of poverty of small scale farmers. Agricultural credits are issued based on the confidence in the users promise and ability to pay back at a specified future date. It is the monetization of exchanging of cash in the present for a promise to repay in future with or without interest. Without the willingness and ability to repay, the promise to repay at a future date would be futile. For any aspect of agricultural production needs funds, since it enhances acquisition of all other resources required for reasonable and effective operation (Olagunju and Ajiboye, 2010). On the role, duties and functions of ACGSF and its impacts enhancing economic development in Nigeria, Ojo and Oluwaseun (2015) found that ACGSF scheme has the tendency of improving macro-economic development when efficiently managed and harnessed.

Accessibility to credit has to be backed up with good management in order to achieve the desired expansion in agricultural production, increased income and eventually prompt repayment of loans. Udoka et al. (2016) posited that inadequate funds constitute a hindrance to investment activities and income growth of poor households in developing countries of the world. Access to credit is a very useful tool in ameliorating poverty among rural poor as it aids the adoption of new and improved technologies required to enhance farmers' levels of income thereby, alleviating poverty. Makarfi and Olukosi (2011) reported that there is a link between growth in livestock rearing, farming and equipment financing for the acquisition of capital assets and Micro Finance Institutions in Kano.

In management of the fund made for agricultural activities known as fund's operations, several challenges bound to occur which were identified as confronting smooth performance. Nwosu et al. (2010) enumerated some of the challenges of the agricultural loan scheme as lack of good administration of credits, loan repayment defaults by beneficiaries, high transactions cost, inappropriate legal securities, and lack of commitment on the part of formal lending institutions to lend to farmers for better productivity

\section{Empirical review}

In Nigeria studies were undertaken by some scholars on the Impact of Agricultural Credit Guarantee Scheme Fund on agricultural sector development. Orok and Ayim (2017) in their study found that the scheme had impact in improving the productivity level of crop farmers. It was further revealed that more funds were granted to crop sector than that of other sectors. Oparinde et al. (2017) in their research on influence of ACGSF on fishery development in Nigeria affirmed that less fund was allocated to fishery sub-sector than crop sub sector of agricultural production. The Gross Domestic Product (GDP) and agricultural output in the crop sector was said to have been increased tremendously with the ACGSF in Nigeria (Olajide et al., 2012). Zakaree (2014) in a study on the impact of Agricultural Credit Guarantee Scheme Fund (ACGSF) in domestic food Supply in Nigeria revealed that the ACGSF scheme has negative and statistically significant impact on the domestic food production. He further expressed that the negative impact can be attributed to a long delay in disbursement of loan to the farmers in the rural areas. Since most of the banks are located in the cities, in some cases where loans are approved, it arrives too late for it to fulfil the purpose for which it was intended. In a study on Economic revitalization through agriculture: role of Agricultural Credit Guarantee Scheme Fund in Nigeria, Tiamiyu et al. (2017) reported that a significant proportion of change in agricultural GDP was due to increase in Credit Funds supplied to farmers.

On the site of the government efforts in boosting the agricultural scheme, Olajide et al., (2012) however focused on government spending as the only explanatory variable for agricultural output. In another work, Udoh (2011) investigated the relationship between public expenditure, private investment and agricultural output growth in Nigeria over the period 1970-2008, using the error correction model and revealed that increased in 
public expenditure has a positive influence on the growth of the agricultural output. Isiorhovoja (2017) in his studies on the effects of Niger Delta Development Commission (NNDC) on ACGSF in the oil producing states for the period 1991-2011, found that there were no much changes in the number and value of loans guaranteed among the nine states for the period under review. Igwe and Esonwume (2011) examined the role of Abia State government as it affects agricultural output in Nigeria using Ordinary Least Squares (OLS) regression analysis and found that total land area cropped, total annual rainfall and total population were strong factors that majorly influenced total crop output in the states. However, since the study only focused on one out of thirty-six (36) states in Nigeria, it may not accurately represent the true situation of the country. Hence, this study addressed these gaps. Using aggregated approach, considered Agricultural Credit Guarantee Scheme Funds as an important variable that affects food supply in Nigeria.

\section{DATA AND METHODS}

\section{Study area}

The study area is Nigeria, which is one of the West African countries. It shares land border with Cameroon and Chad in the east, republic of Benin in the west and Niger republic in the north. The boundary at the southern part is the coast Gulf of Guinea and with Lake Chad at the northeast. The country is located in the tropics and approximately at latitude $10^{\circ} 00^{\prime} \mathrm{N}$ and longitude $8^{0} 00^{\prime} \mathrm{E}$ with annual rainfall ranges from $2000-4000 \mathrm{~mm}$ in the south and less than $2000 \mathrm{~mm}$ in the north. Nigeria has a mean minimum temperature of $30-32^{\circ} \mathrm{C}$ in the Southern and $30-35^{\circ} \mathrm{C}$ in northern parts and three prominent vegetation belt found in different part. The vegetation distribution is dense forest in the south, savannah in the middle region and Sahel savannah in the northern region. (Oruonye, 2014). The country has an estimated population of over 182 million people in 2015 (NBS, 2017) and is an agrarian nation with variety of crops grown across the country.

\section{Method of data collection}

Secondary data were collected from published materials by Central Bank of Nigeria (CBN) and National Bureau for Statistics (NBS) on ACGSF annual reports for the period under consideration. The data collected include annual report on the number and volume of loan guaranteed and the output of various agricultural sectors.

\section{Analytical techniques}

Descriptive statistics and multiple regressions were used to analyse the data collected. Graphs and percentages were used to address objective (i) while multiple regression analysis was used to address objective (ii) using Statistical Package for Social Sciences (SPSS).

In this study, the four functional forms, linear, semi-log, double-log and exponential equations were used and the equation with best fit or lead equation was picked for interpretation.

The general functional form adopted for this analysis is given as in Eq. (1):
$\mathrm{Y}=\beta_{0}+\beta_{1} x_{1}+\beta_{2} x_{2}+\beta_{3} x_{3}+U$

Where:

Y Total Gross Domestic Product (GDP) of crop sector, livestock sector and fishery sectors in NGN;

$\beta_{0}$ Constant;

$\beta_{1}-\beta_{3}$ Coefficient of volumes of credits guaranteed by ACGSF to various agricultural sectors;

$x_{1}$ Volume of credits guaranteed by ACGSF to (CS)crop sector (NGN);

$x_{2}$ Volume of credits guaranteed by ACGSF to (LS) livestock sector (NGN);

$x_{3}$ Volume of credits guaranteed by ACGSF to (FS) fishery sector (NGN);

$U$ Error term.

The explicit forms of the equations tried are presented in Eq. (2) to (5).

Linear function as in Eq. (2)

$\mathrm{Y}=\beta_{0}+\beta_{1} x_{1}+\beta_{2} x_{2}+\beta_{3} x_{3}+U$

Semi- log function as in Eq. (3)

$\mathrm{Y}=\beta_{0}+\beta_{1} \log x_{1}+\beta_{2} \log x_{2}+\beta_{3} \log x_{3}+U$

Double $\log$ function as in Eq. (4)

$\log Y=\beta_{0}+\beta_{1} \log x_{1}+\beta_{2} \log x_{2}+\beta_{3} \log x_{3}+U$

Exponential function as in Eq. (5)

$\log \mathrm{Y}=\beta_{0}+\beta_{1} x_{1}+\beta_{2} \log x_{2}+\beta_{3} \log x_{3}+U$

The dependent variable is the aggregate GDP of crop sub-sector, livestock sub-sector and fishery sub-sector in Nigeria from 1998 to 2017 measured in naira (NGN). The independent variable is the volume of credits guaranteed by ACGSF to various sub-sectors from 1998-2017 measured in naira (NGN).

\section{RESULTS AND DISCUSSION}

Trend in annual volume of credits guaranteed by ACGSF (1998 -2017)

Figure 1shows the trend in total credit supply by ACGSF to agricultural sector. It revealed that there was a steady and consistent rise in Agricultural credit supply by the scheme. However, in 2010, there was a decrease in the credit supply from $8,349,509.28$ NGN (52,844 USD) of 2009 to $7,740,507.63 \mathrm{NGN}(48,990.55$ USD) and a further drop from 9,706,761.23 NGN (61,320.70 USD) to 9,424,449.95 NGN (29,813.83 USD) in 2012 and 2013 respectively. This is in line with the findings of Orok and Ayim (2017) who reported that credit supply to agriculture by ACGSF has been rising in an inconsistent trend. The highest volume of credit guarantee was in 2014 with a value of $12,997,004.15$ NGN (70,444.47 USD). This increase was caused by the incentive put in place by the scheme to achieve development in agricultural sector and thus improve domestic food supply. This incentive involves the increase in the limit of the credit guarantee to individuals and corporate bodies. For example, the limit granted to individuals was increased from 5,000 NGN (27.10 USD) to $20,000 \mathrm{NGN}$ (108.40 USD), without collateral while the limit guarantee for those with collateral was increased from 100,000 NGN (542.00 USD) 
to 500,000 NGN (2,710.02 USD). On the other hand, for corporate bodies and cooperative societies, the guarantee limit was increased from 1million NGN (920.42 USD) to 5 million NGN (34602.07 USD) (Zakaree, 2014). Nevertheless, in 2015, the newly elected government, in its first tenure focused its attention on fighting corruption thereby neglecting the agricultural sector, which might have resulted in the sharp drop in the credit guarantee to $3,880,672.60$ NGN $(15,553.79$ USD) in 2017.

Trend in ACGSF volume of credits guaranteed to crop sub-sector (1998-2017)

Table 1 indicated the changes in volume of agricultural credit guaranteed to crop sub-sector. It shows that there had been a consistent increase in the volume of funds guaranteed to crop sub-sector from 79,114.66 NGN
(3,614.19 USD) in 1998 to $5,816,197.46$ NGN $(36,811.37$ USD) in 2009. Though the period between 2002 and 2005 witnessed substantial increase in the volume of credit guaranteed to crop subsector from 939,556.60 NGN $(8,464.47$ USD) to $2,665,725.70 \mathrm{NGN}(19,893.47$ USD), the increases were not proportionate to that in volume of credit guarantee to agricultural sector. This is explained by the decline in the percentage change in volume of credit guaranteed to crop subsector (from $89.3 \%$ to $87.5 \%$ ). In the year 2006 there was a percentage increase to $88.5 \%$, in the period from 2010 to 2017 , there was a sporadic rise and fall in the volume of credit guaranteed and percentage changes in the volumes as well.

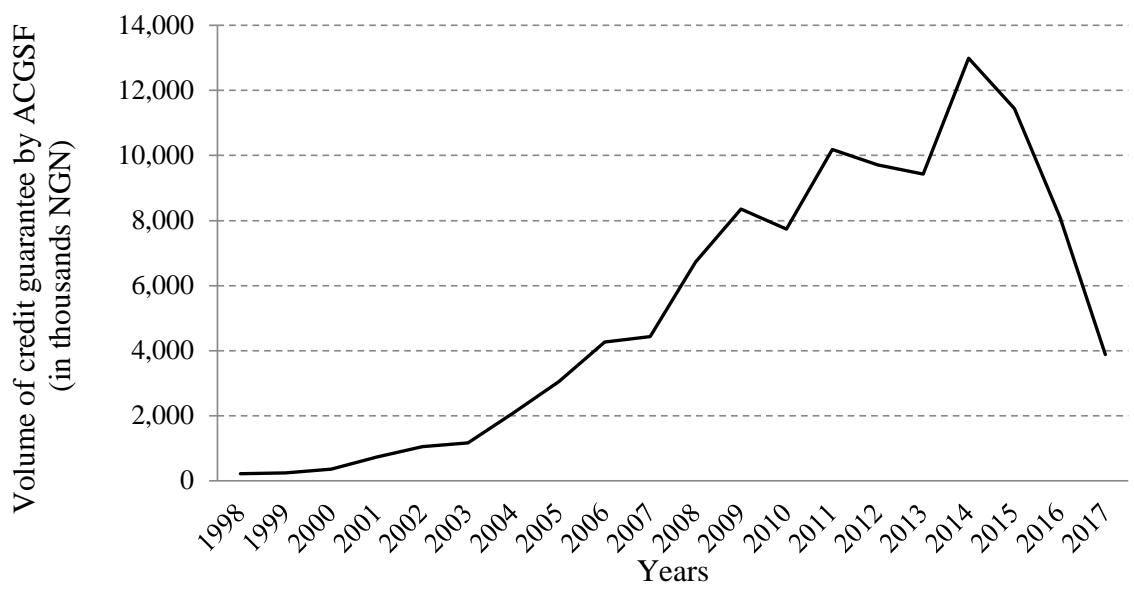

Figure 1: Trend in ACGSF annual volume of credits guaranteed (1998 -2017) Source: CBN and NBS database, 2018

Table 1: ACGSF volume of credits supply by to crop sub-sector (1998-2017)

\begin{tabular}{|c|c|c|c|c|}
\hline $\mathrm{S} / \mathrm{N}$ & Year & $\begin{array}{l}\text { Volume of credit } \\
\text { guaranteed by ACGSF } \\
\text { in thousands NGN }\end{array}$ & $\begin{array}{l}\text { Volume of credit guaranteed } \\
\text { by ACGSF to crop sub-sector } \\
\text { in thousands NGN }\end{array}$ & $\begin{array}{l}\% \text { Volume of credit } \\
\text { guaranteed by ACGSF } \\
\text { to crop sub-sector }\end{array}$ \\
\hline 1 & 1998 & $215,697.20$ & $79,114.66$ & 36.7 \\
\hline 2 & 1999 & $246,082.50$ & $157,801.20$ & 64.1 \\
\hline 3 & 2000 & $361,450.40$ & $308,606.20$ & 85.4 \\
\hline 4 & 2001 & $728,545.40$ & $622,694.70$ & 85.5 \\
\hline 5 & 2002 & $1,051,589.80$ & $939,556.60$ & 89.3 \\
\hline 6 & 2003 & $1,164,460.40$ & $1,023,901.60$ & 87.9 \\
\hline 7 & 2004 & $2,083,744.70$ & $1,824,664.70$ & 87.6 \\
\hline 8 & 2005 & $3,046,738.50$ & $2,665,725.70$ & 87.5 \\
\hline 9 & 2006 & $4,263,060.30$ & $3,771,179.28$ & 88.5 \\
\hline 10 & 2007 & $4,425,861.84$ & $3,914,174.29$ & 88.4 \\
\hline 11 & 2008 & $6,721,074.56$ & $5,189,080.28$ & 77.2 \\
\hline 12 & 2009 & $8,349,509.28$ & $5,816,197.46$ & 69.7 \\
\hline 13 & 2010 & $7,740,507.63$ & $5,511,322.13$ & 71.2 \\
\hline 14 & 2011 & $10,189,604.24$ & $6,906,662.61$ & 67.8 \\
\hline 15 & 2012 & $9,706,761.23$ & $6,762,283.92$ & 69.7 \\
\hline 16 & 2013 & $9,424,449.95$ & $5,978,827.70$ & 63.4 \\
\hline 17 & 2014 & $12,997,004.15$ & $7,999,413.60$ & 61.5 \\
\hline 18 & 2015 & $11,441,978.83$ & $7,439,662.73$ & 65.0 \\
\hline 19 & 2016 & $8,104,810.63$ & $5,906,403.74$ & 72.9 \\
\hline 20 & 2017 & $3,880,672.60$ & $2,351,267.22$ & 60.6 \\
\hline
\end{tabular}

Source: Analysis from Own calculation based on CBN and NBS database, 2018 
Trend in ACGSF volume of credit guaranteed to livestock sub-sector (1998-2017)

Table 2 and Figure 2 depict the movement in agricultural credit supply by ACGSF to the livestock sub-sector. It revealed that credit supply by ACGSF directed to livestock increased consistently in the period under review, from 17, 054.34 NGN (779.09 USD) in 1998 to $368,151.00$ NGN $(2,828.67$ USD) in 2006. In 2007 there was a drop in the volume of credit guaranteed to livestock sub-sector. This position changed in 2008 where the funding began to fluctuate until it peaked at 2,342,247.00 NGN $(12,695.10$ USD) in 2014 then started declining from 2015 up to 2017. Despite the steady rise in volume of credit guaranteed to the sub-sector between 1998 at 17,054.34 NGN (779.09 USD) and 2006 at 368,151.00 NGN (2,828.66 USD) there was continues fluctuation in the percentage changed in the volume of credit guaranteed to the livestock sector.

ACGSF volume of credits guaranteed to fishery subsector (1998-2017)

Table 3 and Figure 3 show the trend in Agricultural Credit Guarantee Scheme Fund supply to the fishery sub-sector from 1998-2017. It shows that there was a consistent but meagre increase in credit supply to this sub-sector from 1998-2007 however, in 2008 and 2009 there was a sharp increase from $140,690.00 \mathrm{NGN}(1,194.81 \mathrm{USD})$ to 368 , 630 NGN (2,333.10 USD) and then 708,621.20 NGN (4,484.94 USD). Table 3 indicates an erratic movement in the percentage change in the volume of credit guaranteed to fishery sub-sector. The Figure 3 also indicates that the fishery sub-sector is the least guaranteed by the ACGSF. The result agreed with the findings of Oparinde $\boldsymbol{e t}$ al. (2017) that fishery sub-sector was the least financed in all agricultural sectors ACGSF in Nigeria. This implies that little importance is attached to sustainable increase in fish production by the scheme. It is important to state that failure to increase the volume of loan allocated to the fishery sub-sector implies inviting international communities to flood Nigerian markets with both healthy and unhealthy fishes and this will be detrimental to the citizens of the Nation both economically and medically.

Trend in the volume of credit guaranteed to various subsectors

Table 4 shows the trend in agricultural credit guaranteed to crop, livestock and fishery sub-sectors. It shows that agricultural sector recorded the highest volume of credit guarantee in the year 2014 with the value of 12,997,004.15 NGN (70,444.46 USD) it further revealed that the distribution among the sub-sectors favoured crop subsector the most as it always recorded the highest volume of credit guaranteed, followed by livestock sub-sector, then fishery sub-sector. In the year 2014, crop sub-sector recorded the highest volume of credit guaranteed with the value of $7,999,413.60 \quad \mathrm{NGN} \quad(43,357.25$ USD) representing $61.5 \%$ of the volume of credit guaranteed to agricultural sector. It was followed by the livestock subsector with the value of 2,342,247.00 NGN $(12,695.10$ USD) represented $18 \%$ of the volume of credit guaranteed to agriculture while fishery subsector had the least value of $453,426.00 \mathrm{NGN}(2,457.5 \mathrm{USD})$ represented $3.5 \%$ of the total volume of credit guaranteed to agriculture. This implies that the scheme gave little attention to fishery subsector as compared to the other two sub-sectors. In Table 4 , it was also depicted that the highest credit guaranteed to fishery sub-sector in the period under review was 708,621.20 NGN (4,484.94 USD) represented 8.49\% in the year 2009, thoughit was still the least funded subsector in that year as compared to the credit guaranteed to other sub-sectors.

Table 2: ACGSF volume of credit guaranteed to livestock sub sector from 1998-2017

\begin{tabular}{lrrrr}
\hline S/N & Year & $\begin{array}{l}\text { Volume of credit guaranteed } \\
\text { by ACGSF in thousands NGN }\end{array}$ & $\begin{array}{l}\text { Volume of credit guaranteed } \\
\text { by ACGSF to livestock } \\
\text { sub-sector in thousands NGN }\end{array}$ & $\begin{array}{c}\text { \% Volume of credit guaranteed by } \\
\text { ACGSF to livestock sub-sector }\end{array}$ \\
\hline 1 & 1998 & $215,697.20$ & $17,054.34$ & 7.9 \\
2 & 1999 & $246,082.50$ & $17,630.20$ & 7.2 \\
3 & 2000 & $361,450.40$ & $27,307.20$ & 7.6 \\
4 & 2001 & $728,545.40$ & $60,415.70$ & 8.3 \\
5 & 2002 & $1,051,589.80$ & $64,449.60$ & 6.1 \\
6 & 2003 & $1,164,460.40$ & $106,962.80$ & 9.2 \\
7 & 2004 & $2,083,744.70$ & $191,659.00$ & 9.2 \\
8 & 2005 & $3,046,738.50$ & $250,677.80$ & 8.2 \\
9 & 2006 & $4,263,060.30$ & $368,151.00$ & 8.6 \\
10 & 2007 & $4,425,861.84$ & $353,487.60$ & 8.0 \\
11 & 2008 & $6,721,074.56$ & $1,108,484.00$ & 16.5 \\
12 & 2009 & $8,349,509.28$ & $1,725,801.00$ & 20.7 \\
13 & 2010 & $7,740,507.63$ & $1,305,433.00$ & 16.9 \\
14 & 2011 & $10,189,604.24$ & $1,882,283.00$ & 18.5 \\
15 & 2012 & $9,706,761.23$ & $1,878,043.00$ & 19.3 \\
16 & 2013 & $9,424,449.95$ & $1,883,008.00$ & 20.0 \\
17 & 2014 & $12,997,004.15$ & $2,342,247.00$ & 18.0 \\
18 & 2015 & $11,441,978.83$ & $1,444,013.00$ & 12.6 \\
19 & 2016 & $8,104,810.63$ & $1,169,448.00$ & 14.4 \\
20 & 2017 & $3,880,672.60$ & $546,820.00$ & 14.1 \\
\hline
\end{tabular}

Source: Analysis from Own calculation based on CBN and NBS database, 2018 


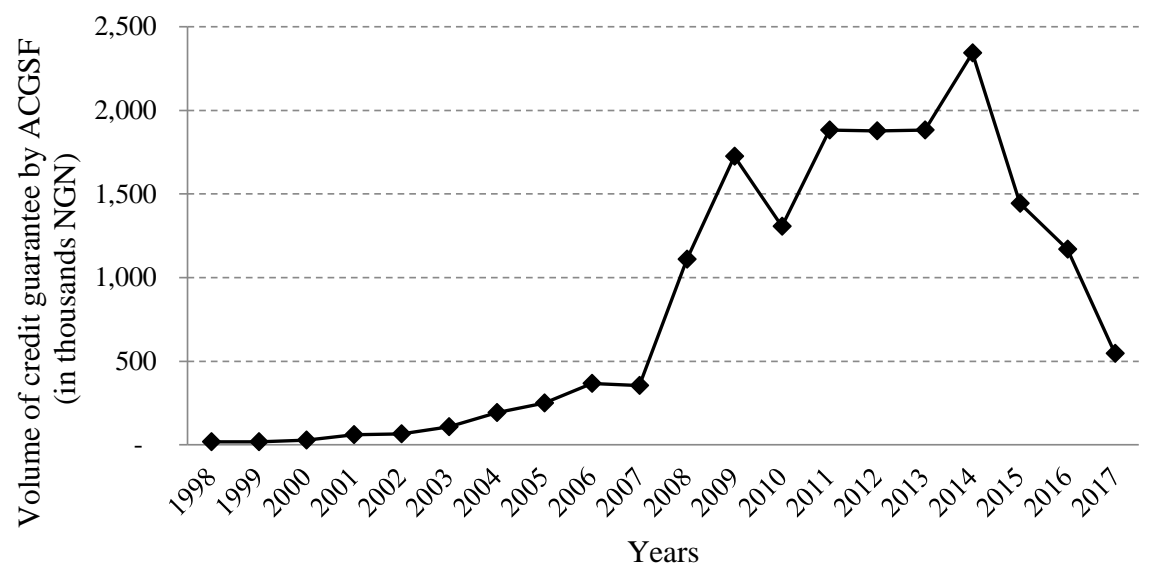

Figure 2: Movement in the volume of agricultural credit guaranteed to the livestock sector (1998-2017) Source: CBN and NBS database, 2018

Table 3: ACGSF volume of credit guaranteed to fishery sub-sector (1998-2017) $\mathrm{S} / \mathrm{N}$ Year Volume of credit guaranteed by Volume of credit guaranteed by ACGSF in thousands NGN

\section{ACGSF to fishery sub-sector in} thousands NGN

$215,697.20$
$246,082.50$
$361,450.40$
$728,545.40$
$, 051,589.80$
$164,460.40$
$2,083,744.70$
$3,046,738.50$
$4,263,060.30$
$4,425,861.84$
$6,721,074.56$
$8,349,509.28$
$7,740,507.63$
$0,189,604.24$
$9,706,761.23$
$9,424,449.95$
$12,997,004.15$
$1,441,978.83$
$8,104,810.63$
$3,880,672.60$

$\%$ Volume of credit guaranteed by ACGSF to fishery subsector

\begin{tabular}{rl}
428.60 & 0.20 \\
599.10 & 0.24 \\
899.00 & 0.25 \\
$15,742.20$ & 2.16 \\
$12,069.30$ & 1.15 \\
$13,150.00$ & 1.13 \\
$18,240.00$ & 0.88 \\
$77,490.00$ & 2.54 \\
$14,400.00$ & 2.68 \\
$40,690.00$ & 3.18 \\
$68,630.00$ & 5.48 \\
$08,621.20$ & 8.49 \\
$61,128.00$ & 5.96 \\
$90,167.50$ & 5.79 \\
$778,311.90$ & 3.90 \\
$71,403.00$ & 3.94 \\
$53,426.00$ & 3.49 \\
$85,089.00$ & 4.24 \\
$44,763.00$ & 5.49 \\
$775,454.00$ & 7.10 \\
\hline
\end{tabular}

Source: Analysis from CBN and NBS database, 2018

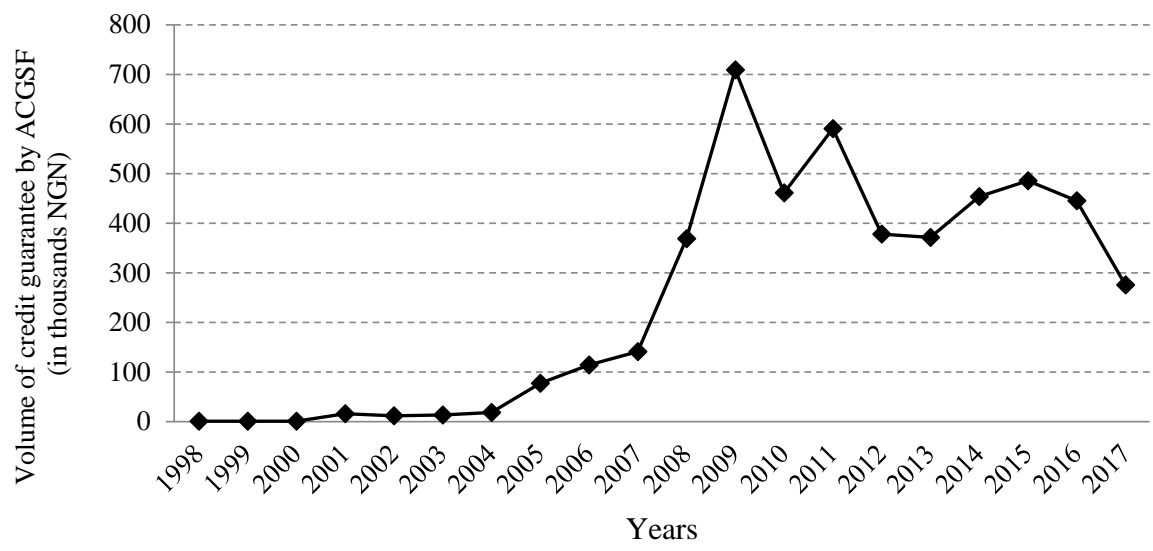

Figure 3: ACGSF volume of credit to fishery sub- sector (1998-2017) Source: CBN and NBS database, 2018 
Table 4: Credit guaranteed to various agricultural sub-sectors from 1998-2017

\begin{tabular}{|c|c|c|c|c|c|c|c|c|}
\hline $\mathrm{S} / \mathrm{N}$ & Year & $\begin{array}{l}\text { Volume of } \\
\text { credit } \\
\text { guaranteed by } \\
\text { ACGSF to } \\
\text { agric. sector in } \\
\text { thousands } \\
\text { NGN }\end{array}$ & $\begin{array}{l}\text { Volume of } \\
\text { credit } \\
\text { guaranteed by } \\
\text { ACGSF to } \\
\text { crop sub- } \\
\text { sector in } \\
\text { thousands } \\
\text { NGN }\end{array}$ & $\begin{array}{l}\% \text { Volume } \\
\text { of credit } \\
\text { guaranteed } \\
\text { by ACGSF } \\
\text { to crop sub- } \\
\text { sector in \% }\end{array}$ & $\begin{array}{l}\text { Volume of } \\
\text { credit } \\
\text { guaranteed by } \\
\text { ACGSF to } \\
\text { livestock sub- } \\
\text { sector in } \\
\text { thousands } \\
\text { NGN }\end{array}$ & $\begin{array}{l}\% \text { Volume } \\
\text { of credit } \\
\text { guaranteed } \\
\text { by ACGSF } \\
\text { to livestock } \\
\text { sub-sector } \\
\text { in } \%\end{array}$ & $\begin{array}{l}\text { Volume of } \\
\text { credit } \\
\text { guaranteed } \\
\text { by ACGSF } \\
\text { to fishery } \\
\text { sub-sector } \\
\text { in thousands } \\
\text { NGN }\end{array}$ & $\begin{array}{l}\% \text { Volume } \\
\text { of credit } \\
\text { guaranteed } \\
\text { by ACGSF } \\
\text { to fishery } \\
\text { sub-sector } \\
\text { in } \%\end{array}$ \\
\hline 1 & 1998 & $215,697.20$ & $79,114.66$ & 36.7 & $17,054.34$ & 7.9 & 428.60 & 0.20 \\
\hline 2 & 1999 & $246,082.50$ & $157,801.20$ & 64.1 & $17,630.20$ & 7.2 & 599.10 & 0.24 \\
\hline 3 & 2000 & $361,450.40$ & $308,606.20$ & 85.4 & $27,307.20$ & 7.6 & 899.00 & 0.25 \\
\hline 4 & 2001 & $728,545.40$ & $622,694.70$ & 85.5 & $60,415.70$ & 8.3 & $15,742.20$ & 2.16 \\
\hline 5 & 2002 & $1,051,589.80$ & $939,556.60$ & 89.3 & $64,449.60$ & 6.1 & $12,069.30$ & 1.15 \\
\hline 6 & 2003 & $1,164,460.40$ & $1,023,901.60$ & 87.9 & $106,962.80$ & 9.2 & $13,150.00$ & 1.13 \\
\hline 7 & 2004 & $2,083,744.70$ & $1,824,664.70$ & 87.6 & $191,659.00$ & 9.2 & $18,240.00$ & 0.88 \\
\hline 8 & 2005 & $3,046,738.50$ & $2,665,725.70$ & 87.5 & $250,677.80$ & 8.2 & $77,490.00$ & 2.54 \\
\hline 9 & 2006 & $4,263,060.30$ & $3,771,179.28$ & 88.5 & $368,151.00$ & 8.6 & $114,400.00$ & 2.68 \\
\hline 10 & 2007 & $4,425,861.84$ & $3,914,174.29$ & 88.4 & $353,487.60$ & 8.0 & $140,690.00$ & 3.18 \\
\hline 11 & 2008 & $6,721,074.56$ & $5,189,080.28$ & 77.2 & $1,108,484.00$ & 16.5 & $368,630.00$ & 5.48 \\
\hline 12 & 2009 & $8,349,509.28$ & $5,816,197.46$ & 69.7 & $1,725,801.00$ & 20.7 & $708,621.20$ & 8.49 \\
\hline 13 & 2010 & $7,740,507.63$ & $5,511,322.13$ & 71.2 & $1,305,433.00$ & 16.9 & $461,128.00$ & 5.96 \\
\hline 14 & 2011 & $10,189,604.24$ & $6,906,662.61$ & 67.8 & $1,882,283.00$ & 18.5 & $590,167.50$ & 5.79 \\
\hline 15 & 2012 & $9,706,761.23$ & $6,762,283.92$ & 69.7 & $1,878,043.00$ & 19.3 & $378,311.90$ & 3.90 \\
\hline 16 & 2013 & $9,424,449.95$ & $5,978,827.70$ & 63.4 & $1,883,008.00$ & 20.0 & $371,403.00$ & 3.94 \\
\hline 17 & 2014 & $12,997,004.15$ & $7,999,413.60$ & 61.5 & $2,342,247.00$ & 18.0 & $453,426.00$ & 3.49 \\
\hline 18 & 2015 & $11,441,978.83$ & $7,439,662.73$ & 65.0 & $1,444,013.00$ & 12.6 & $485,089.00$ & 4.24 \\
\hline 19 & 2016 & $8,104,810.63$ & $5,906,403.74$ & 72.9 & $1,169,448.00$ & 14.4 & $444,763.00$ & 5.49 \\
\hline 20 & 2017 & $3,880,672.60$ & $2,351,267.22$ & 60.6 & $546,820.00$ & 14.1 & $275,454.00$ & 7.10 \\
\hline
\end{tabular}

Source: Own calculation based on CBN and NBS database, 2018

Table 5: The effect of ACGSF on agricultural output in Nigeria

\begin{tabular}{|c|c|c|c|c|}
\hline Variable & Coeff. & Std. error & t-Statistic & Prob. \\
\hline $\mathrm{C}$ & 0.8958 & 0.8515 & 1.0519 & 0.3085 \\
\hline LOG X1 (CS) & 0.1607 & 0.0408 & 3.9309 & $0.0112 *$ \\
\hline LOG X2 (LS) & 0.2320 & 0.1243 & 1.8665 & $0.0537 * *$ \\
\hline LOGX3 (FS) & 0.1920 & 0.0790 & 2.4303 & $0.0181 *$ \\
\hline R-squared & 0.8523 & \multicolumn{2}{|c|}{ Mean dependent var } & 5.5056 \\
\hline Adjusted R-squared & 0.8214 & \multicolumn{2}{|c|}{ S.D. dependent var } & 0.6713 \\
\hline S.E. of regression & 0.2928 & \multicolumn{2}{|c|}{ Akaike info criterion } & 0.5500 \\
\hline Sum squared resid & 1.3606 & & Schwarz criterion & 0.7492 \\
\hline Log likelihood & -1.5009 & \multicolumn{2}{|c|}{ Hannan-Quinn criter. } & 0.5889 \\
\hline F-statistic & 28.2373 & \multicolumn{2}{|c|}{ Durbin-Watson stat } & 1.8503 \\
\hline Prob(F-statistic) & 0.000001 & & & \\
\hline
\end{tabular}

Note: $(*)$ and $(* *)$ denote significance of results at $1 \%$ and $5 \%$ levels respectively.

Source: Own calculation based on CBS and NBS database, 2018

The effect of ACGSF on agricultural output in Nigeria The result in Table 5 shows the multiple regression results on the influence of ACGSF on the agricultural output in Nigeria. The results in the led equation with best fit (Eq.5) was picked and interpreted for the analysis. It revealed that ACGSF credit guaranteed to farmers had a significant effect on the farmers' output (farmers' GDP) in the country. The results indicated that the coefficients of ACGSF on Crop Sector (CS), Livestock Sector (LS) and Fishery Sector (FS) variables were positive and significant at $1 \%$ and $5 \%$ levels. The coefficient of the ACGSF on crop sector (CS) was 0.1607 , meaning that a unit increase in the volume of credit supply to crop production would lead to $16.07 \%$ increase in the GDP of the farmers in the crop sector. The coefficient of the ACGSF on livestock sector (LS) variable was 0.2320 , meaning that a unit increase in the volume of credit supply to livestock production would lead to $23.20 \%$ increase in the GDP of farmers in livestock production. Also, the coefficient of the ACGSF on fishery sector (FS) variable was 0.1920 at $1 \%$ level of significance, meaning that a unit increase in the volume of credit supply to fishery production would lead to $19.20 \%$ increase in the GDP of fishery farmers in Nigeria.

The multiple determination coefficients $\left(\mathrm{R}^{2}\right)$ of 0.8523 implied that credit supply by ACGSF to the various sectors accounted for $85 \%$ of variations in the output of the farmers in various sub-sectors. Furthermore, the signs 
of the coefficients were positive and in conformity with $a$ priori expectations that access to credit are expected to empower farmers to procure more inputs at the right time to boost agricultural production. The result agreed with the findings of Orok and Ayim (2017), that the AGCSF effect on Crop sector was positive with great impact on the GDP of the farmers involved in crop production in the country The higher proportionate increase in agricultural GDP for every unit increase in ACGSF implied that credit supply by the scheme has multiplier effects on the growth of agricultural share of GDP. It therefore means that credit supply is an appropriate strategy to stimulate agricultural production for economic revitalization. The finding was in consonance with that of Okezie and Erendu (2016) who found a higher coefficient of multiple determinations $\left(\mathrm{R}^{2}\right)$ value of 0.928 , indicating that credit supply to the agricultural sector over time accounted for about $93 \%$ variations in the output of the farmers in the Country.

\section{CONCLUSIONAND RECOMMENDATIONS}

The study assessed the trends in the flow of ACGSF credits to farmers and its effects on agricultural output in Nigeria. The specific objectives of the study were to; examine the trend in the volume of agricultural loans guaranteed to different sectors of agriculture by ACGSF from the year 1998 to 2017, and analyse the effects of credit volumes guaranteed by ACGSF on agricultural output in Nigeria. Secondary data were sourced from Central Bank of Nigeria, Nigeria Bureau for Statistics, Nigeria Agriculture, Cooperative and Rural Development Bank and other commercial institutions in the Country. The data were analysed using descriptive and inferential statistics.

The result revealed that there was appreciably definite pattern in government's financing of the agricultural sector, through the volume of loans supplied to the sectors in the time period under review (1998 - 2017). Credit supply to agriculture from the scheme has been increasing but in an inconsistent trend. It was observed in the crop sub-sector that there was a consistent increase in credit from 1998 to 2009 . The result revealed that credit supply by the scheme directed to livestock sub sector rose consistently in the period of study but there was no reasonable increase in credit supply to the sub-sector from 1998-2007 as compared to other agricultural sub-sectors. It was also found that the fishery sub-sector was the least funded sub-sector.

The multiple determination coefficients $\left(\mathrm{R}^{2}\right)$ of 0.8523 was obtained, implying that credit supply by ACGSF to the various sectors accounted for $85 \%$ of variations in the output of the sub-sectors. The coefficients of ACGSF on crop sector (CS), livestock sector (LS) and fishery sector (FS) were $0.1607,0.2320$ and 0.2110 respectively. The signs were all positive and significant at $1 \%$ and $5 \%$ levels. The results are in conformity with $a$ priori expectation that access to credit is expected to empower farmers to procure more inputs at the right time to boost agricultural production.

Based on the findings, the study concludes that ACGSF has a positive effect on agricultural output in Nigeria as evident in the result of regression analysis. It is observed that there has been increased in the volume of agricultural credit guaranteed to the various sub-sectors of agriculture. ACGSF has significant impact on agricultural output and is seen to be a vital element in agricultural development in Nigeria. Furthermore, it was revealed that the fishery sub-sector was the least funded sub-sector but with more impact on the GDP of the farmers in the sector. Therefore, it is expected that farmers, government, agricultural agencies, financial institutions and allied bodies such as agricultural companies, should give more preference to the scheme to boost production capabilities and consequently improve farmers' standard of living.

Based on the findings, it was recommended that with relative low level of funding to the fishery sub-sector effort should be made by ACGSF to step up more funding to the sub-sector. Private sector investment into agriculture should be encouraged by all tiers of governments in utilizing the scheme for better standard of living of the farmers. Financial institutions should encourage agricultural sector by partnering more with the CBN on the ACGSF for developing and making facilities available to the farmers at low interest rates to enable them embark on large scale production. Finally, research on effect of ACGSF on other agricultural sub-sectors like forestry and horticultural sectors should be encouraged.

\section{Acknowledgments}

The authors are most grateful to the lecturers in the Department of Agricultural Economics and Extension, Taraba State University, Jalingo for their contributions and constructive criticisms of the final results of the research work. Appreciation goes to the Managers of Zenith Bank Plc for their support amidst tight schedules. We are also grateful to the Nigeria Agricultural Cooperative and Rural Development Bank (NACRDB), National Bureau for Statistics (NBS) and Central Bank of Nigeria (CBN) Branches in Jalingo, the Taraba State Capital for releasing some of their data, literatures and books for this research work.

\section{REFERENCES}

ASHAOLU, O. F., MOMOH, S., PHILlIP, B. B., \& TIJANI, I. A. (2011). Microcredit Effect on Agricultural Productivity: A Comparative Analysis of Rural Farmers in Ogun State, Nigeria. International Journal of Applied Agricultural and Apicultural Research, 7(1\&2), 23-35.

CBN. CENTRAL BANK OF NIGERIA (2013). Annual Report and Statement of Accounts for 2013, Abuja. https://www.cbn.gov.ng/Documents/cbnannualreports asp

CHAMBER, R., \& CONWAY, G. R. (1991). Sustainable rural livelihood, practical concept for $21{ }^{\text {st }}$ Century. IDS discussion paper 296, $33 \quad$ pp. https://publications.iwmi.org/pdf/H 32821.pdf

ANTHONY, E. (2010). Agricultural credit and economic growth in Nigeria: an empirical analysis. Business and Economics Journal. 1(2010), 1-10. https://astonjournals.com/manuscripts/Vol2010/BEJ14_Vol2010.pdf

BADIRU, I. O. (2010). Review of small farmer access to 
agricultural credit in Nigeria. IFPRI Policy Note No. 25.

https://ebrary.ifpri.org/digital/collection/p15738coll2/ id/4936/

IGWE, K., \& ESONWUME, C. (2011). Determinants of agricultural output: Implication on Government Funding of Agricultural Sector in Abia State, Nigeria. Journal of Economics and Sustainable Development. 2(4),86-91.

https://www.iiste.org/Journals/index.php/JEDS/article /view/344

ISIORHOVOJA, R. A. (2017). Comparative Statistics on the Activities of Agricultural Credit Guarantee Scheme Fund (ACGSF) Among Oil Producing States of Nigeria. Mediterranean Journal of Social Science 8(1), 105-109.

MAKARFI, A. M., \& OLUKOSI, J. O. (2011). Microfinance institutions as vehicles for sustainable credit access by the poor in Kano State, Nigeria. European Journal of Finance and Banking Research, 4(4), http://globip.com/contents/articles/european-vol4article4.pdf

NBS. NATIONAL BUREAU OF STATISTICS (2017): Nigeria's Gross Domestic Product, Fourth Quarter, 2016, April, $2017 . \quad$ Abuja. https://nigerianstat.gov.ng/elibrary?queries[search]=G DP

NWANKWO, F. O. (2017). Factors affecting access to agricultural loans in Anambra State: An econometric analysis. Asian Journal of Economics, Business and Accounting, $4(3)$,

$1-8$. https://doi.org/10.9734/AJEBA/2017/28822

NWOSU, F. O., OGUOMA, N. N. O., BEN-CHENDO, N. G., \& HENRI-UKOHA, A. (2010). The Agricultural Credit Guarantee Scheme Fund (ACGSF), It roles, problems and prospects in Nigeria's quest for agricultural development. Researcher, 2(2), 87-90.

OJO, O., \& OLUWASEUN, Y. (2015). Agricultural financing and economic development in Nigeria: A study of Agricultural Credit Guarantee Scheme Fund (ACGSF). International Journal of Advances in Management and Economics 4(4), 113-119. file:///C:/Users/Jonny\%20Ato/Downloads/397-12501-PB\%20(3).pdf

OKEZIE, C. R., \& ERENDU, I. (2016). Determinants of agricultural credit supply in Nigeria (1981-2014). IIARD International Journal of Economics and Business Management, 2(6), 2489-2505. https://iiardpub.org/get/IJEBM/VOL.\%202\%20NO.\% 206\%202016/Determinants\%20of\%20Agricultural.pd f

OLAGUNJU, F. I., \& AJIBOYE, A. (2010). Agricultural lending decision: A Tobit Regression Analysis. Agricultural Journal of Food and Nutrition, 10 (5), 2515-2541.

OLAJIDE, O. T., AKINLABI, B. H., \& TIJAN, A. A. (2012). Agriculture resource and economic growth in Nigeria. European Scientific Journal, 8(22), 103-155. DOI: https://doi.org/10.19044/esj.2012.v8n22p\%25p

OPARINDE, L. O., AMOS, T.T., \& ADEESELUKA, M.
(2017). Influence of Agricultural Credit Guarantee Scheme Fund (ACGSF) on fishery development in Nigeria. Scientific Papers Series Management, Economic Engineering in Agriculture and Rural Development, (17)1, 323-332.

http://managementjournal.usamv.ro/pdf/vol.17_1/Art47.p df

OROK, A. B., \& AYIM, S. A. (2017). The Impact of Agricultural Credit Guarantee Scheme Fund on agricultural sector development in Nigeria. International Review of Management and Business Research, 6(3), 1104-1116.

https://www.irmbrjournal.com/papers/1506921605.pdf ORUONYE, E.D. (2014). Geographical Aspect of Jalingo Region. Phimela printing press, Jalingo, Nigeria. Pp 12-18.

SODEEQ A. E., SAKA J. O., LAMIDI, L. O., OGUNTADE, M. I., \& ADEGBUJI, U. O. (2019). The impact of micro credit on food production in Osun State, Nigeria. Journal of Economics and Sustainable Development 10(4), 106-116. DOI: 10.7176/JESD/104-11

TIAMIYU, S. A., BWALA, M. A., \& ALAWODEV, O. (2017). Economic revitalisation through agriculture: Role of Agricultural Credit Guarantee Scheme Fund in Nigeria. Russian Journal of Agricultural and SocioEconomic Sciences, 3(63). 28-34. DOI: https://doi.org/10.18551/rjoas.2017-03.01

UDOH, E. (2011). An examination of public expenditure, private investment and agricultural sector growth in Nigeria: Bounds Testing Approach. International Journal of Business and Social Sciences, 2(13), 285292.

http://ijbssnet.com/journals/Vol._2_No._13_Special_ Issue July 2011/34.pdf

UDOKA, C. O. (2015). Bank loan and advances: Antidote for restructuring the agricultural sector in Nigeria. International Journal of Business Studies and Management 2(3), 9-18. https://www.ijrbsm.org/pdf/v2-i3/2.pdf

UDOKA, C. O. MBAT, D. O., \& DUKE, S. B. (2016). The effect of commercial banks credit on agricultural production in Nigeria. Journal of Finance and Accounting, 4(1), 1-10. DOI: 10.12691/jfa-4-1-1

YUNUS, M. (2011). Grameen Bank. www.grameeninfo.org

YUSUF, H. O., ISHAIAH, P., YUSUF, O., YUSUF, H. A., \& SHUAIBU, H. (2015). The role of informal credit on agriculture: an assessment of small scale maize farmers' utilization of credit in Jemaa Local Government Area of Kaduna State, Nigeria. American Journal of Experimental Agriculture, 5(1), 36-43. DOI: https://doi.org/10.9734/AJEA/2015/12099

ZAKAREE, S. S. (2014). Impact of Agricultural Credit Guarantee Scheme Fund (ACGSF) on domestic food supply in Nigeria. British Journal of Economics, Management \&Trade, 4(8), 1273-1284. 